\title{
The effect of industrial wastes and municipal sewage sludge compost on the quality of virginia fanpetals (SIDA HERMAPHRODITA RUSBY) biomass Part 2. Heavy metals content, their uptake dynamics and bioaccumulation
}

\author{
Ewa Krzywy-Gawrońska \\ Western Pomeranian University of Technology, Szczecin, Department of Land Reclamation and Environmental Chemistry, ul. \\ Słowackiego 17, 71-434 Szczecin, Poland, e:mail:ewa.krzywy-gawronska@zut.edu.pl
}

\begin{abstract}
A single-factor field experiment was carried out at the Cultivar Evaluation Station in Szczecin-Dąbie in 2008-2010. In the experiment, the compost produced with municipal sewage sludge by the GWDA method and high-calcium brown coal ash (furnace waste) were used. The perennial energy crop was a test plant - Virginia fanpetals (Sida hermaphrodita Rusby). It results from the carried out study that Virginia fanpetals biomass contained on average the most manganese $\left(24.7 \mathrm{mg} \cdot \mathrm{kg}^{-1} \mathrm{~d} . \mathrm{m}.\right)$, lead (2.50 mg $\mathrm{kg}^{-1}$ d.m.) and zinc $\left(50.5 \mathrm{mg} \cdot \mathrm{kg}^{-1}\right.$ d.m.) in 2008 , while the most cadmium $\left(0.33 \mathrm{mg} \cdot \mathrm{kg}^{-1} \mathrm{~d} . \mathrm{m}\right.$.), copper (3.78 mg $\mathrm{kg}^{-1}$ d.m.) and nickel (2.57 mg.kg-1 d.m.) in 2010. Average cadmium, copper, manganese, nickel, lead and zinc contents in test plant biomass were higher, respectively by $14.3 \%, 10.0 \%, 7.3 \%$, $19.3 \%, 29.1 \%$ and $6.9 \%$, in the objects where municipal sewage sludge compost had been applied without and with addition of high-calcium brown coal ash when compared to those where only calcium carbonate or high-calcium brown coal ash had been introduced into the soil. The differences in cadmium, copper, manganese, nickel, lead and zinc contents in Virginia fanpetals biomass between particular experimental objects were not significant. The least zinc was absorbed by the test plant biomass in the object with high-calcium brown coal ash being applied in the first year of study and annually. When evaluating the dynamics of heavy metals uptake, it was found to be the lowest in the first year of study (ranging from $4.40 \%$ to $11.0 \%$ ). It increased in the second and the third year of study, oscillating between $29.9 \%$ and $65.7 \%$. The degree of heavy metals accumulation in Virginia fanpetals biomass differed, depending on the fertilisation applied. The bioaccumulation factor of cadmium, copper and nickel after three study years was average, while that of manganese, lead and zinc was intense.
\end{abstract}

Keywords: Virginia fanpetals, heavy metals, content, uptake, bioaccumulation.

\section{INTRODUCTION}

A by-product being developed during technological processes of coal combustion is ashes which contain chemical elements required by plants for their growth and development ${ }^{1-4}$. The problem of proper furnace waste management in Poland and other countries producing electric energy from coal combustion has become a subject of intensive scientific research. This is connected with a need to protect the areas of their storage against dusting and migration of heavy metals to the subsoil and to improve hygienic and aesthetic environmental conditions ${ }^{5,6}$. Municipal sewage sludge and composts produced from them may be used to enrich the soils with organic matter and indispensable nutrients for plants ${ }^{7-14}$.

Certain municipal sewage sludge may be a carrier of heavy metals and organic and microbiological pollutants ${ }^{15-18}$. For that reason, the Minister of Environment issued the Regulation ${ }^{19}$ specifying the permissible contents of heavy metals, quantities of pathogenic microorganisms and parasites in composts produced from municipal sewage sludge designed for ecological and agricultural utilisation and land reclamation. These composts may be used for land reclamation of anthropogenic areas provided that they will be overgrown with plants with intensive growth and unfit for consumption, e.g. energy crops.

Both the ashes and composts produced with municipal sewage sludge may be a potential source of excessive amounts of heavy metals and constitute a threat for the environment. Therefore, their content in composts pro- duced with municipal sewage sludge and ashes (waste), as well as the degree of their utilisation by cultivable plants, should be successively evaluated.

Studies on Virginia fanpetals (Sida Hermaphrodita Rusby) cultivation have been carried out in Europe for many years. This plant is characterised by high tolerance to soil macroelements and heavy metals level. It is a plant which is considered as a renewable energy source (RES).

The rational use of energy from biomass contributes to the reduction of the demand for natural energy raw materials. It has been found that their application is followed by environmental quality improvement through reduction of pollutants passing through to atmosphere and ground waters. As a result, this leads to reduction of the amount of produced wastes being deposited on landfill sites. Under the local conditions in Poland, a primary source of renewable energy is plant biomass. At present, this biomass is mainly delivered by forests and timber industry wastes. The necessity to limit forest felling has contributed to the development of energy crops plantations of perennial species, which include Virginia fanpetals ${ }^{20}$.

Taking into account the favourable effect of composts produced with sewage sludge and the problem with furnace waste storage, a study was carried out that aimed at the determination of the effect of compost produced from municipal sewage sludge by the GWDA method (organic fertiliser) and high-calcium brown coal ash (waste) as a soil de-acidifying fertiliser on the content and the dynamics of cadmium, copper, manganese, nickel and zinc uptake and their bioaccumulation in Virginia 
fanpetals (Sida Hermaphrodita Rusby) biomass during a three-year field experiment.

"Part of this study was conducted within the framework of a research and development project No. 0397/R/ P01/2008/04.

\section{MATERIAL AND RESEARCH METHOD}

The methods for setting up and conducting field experiment have been partly described in part I of the study ${ }^{\mathbf{2 1}}$.

The high-calcium brown coal ash used in this study came from the Pątnów-Adamów-Konin Power Plant Complex. It contained more potassium (5.50 $\mathrm{g} \cdot \mathrm{kg}^{-1}$ d.m.) than phosphorus $\left(2.52 \mathrm{~g} \cdot \mathrm{kg}^{-1} \mathrm{~d}\right.$.m.). This ash partly supplemented potassium deficiency in the compost. It was characterised by a high value of $\mathrm{pH}_{\mathrm{KCl}}$ (11.0) and contained $986 \mathrm{~g} \cdot \mathrm{kg}^{-1}$ dry matter as well as $145 \mathrm{~g} \mathrm{Ca} \cdot \mathrm{kg}^{-1}$ d.m. and $12.5 \mathrm{~g} \mathrm{Mg} \cdot \mathrm{kg}^{-1}$ d.m. No nitrogen or organic carbon was found in the ash.

High calcium content in the ash used in this study (145 $\mathrm{g} \mathrm{Ca} \cdot \mathrm{kg}^{-1}$ d.m.) allowed it to be classified into the group of high-calcium ashes. The total content of cadmium (2.77 $\left.\mathrm{mg} \cdot \mathrm{kg}^{-1}\right)$, manganese $\left(265 \mathrm{mg} \cdot \mathrm{kg}^{-1}\right)$, nickel $\left(12.6 \mathrm{mg} \cdot \mathrm{kg}^{-1}\right)$, zinc $\left(231.0 \mathrm{mg} \cdot \mathrm{kg}^{-1}\right)$ and chromium $\left(20.6 \mathrm{mg} \cdot \mathrm{kg}^{-1}\right)$ in the examined high-calcium brown coal ash used in experiment was higher than in the municipal sewage sludge compost. On the other hand, copper and lead contents (respectively 27.6 and $16.2 \mathrm{in} \mathrm{mg} \cdot \mathrm{kg}^{-1}$ ) were higher in the compost when compared to high-calcium brown coal ash. Taking into consideration the standards referring to the content of heavy metals in fertilisers for soil de-acidification ${ }^{\mathbf{1 8}}$, high-calcium brown coal ash may be included among the factors affecting soil de-acidification without the negative environmental impact.

The compost with municipal sewage sludge used in the experiment, produced by the GWDA method at the Municipal Sewage Treatment Plant in Stargard Szczeciński, corresponded, in respect to its chemical composition, to the standards allowing it to be classified into the group of organic fertilisers. This compost had a $\mathrm{pH}_{2} \mathrm{O}$ of 8.50 and therefore can be applied without fear on strongly acid and acid soils which constitute more than $50 \%$ in Poland. The total content of nitrogen $\left(18 \mathrm{~g} \mathrm{~N} \cdot \mathrm{kg}^{-1} \mathrm{~d} . \mathrm{m}\right.$.) and phosphorus (10.2 $\mathrm{g} \mathrm{P} \cdot \mathrm{kg}^{-1} \mathrm{~d} . \mathrm{m}$.) in this compost was clearly higher than that of potassium $\left(3.58 \mathrm{~g} \mathrm{~K} \cdot \mathrm{kg}^{-1} \mathrm{~d} . \mathrm{m}\right.$.). Therefore, deficiencies of this chemical element should be supplemented in it with potassium mineral fertilisers.

The content of heavy metals in Virginia fanpetals biomass in successive study years was determined in averaged samples from four replications of each fertilisation object. Cadmium, copper, manganese, nickel, lead and zinc contents were determined by the method of atomic absorption spectrometry on a Perkin Elmer AAS 300 spectrometer. The stock solution was obtained after the previous wet mineralisation of plant material according to the Polish standards PN-ISO 11466 and PN-ISO 11047.

The content of heavy metals was processed statistically by the analysis of the variance method using Statistica 8.0 PL computer software package. In the case of significant differences, the Tukey's test was used at the significance level $p=0.05$. The uptake of respective elements in the successive study years was calculated as a product of the content of a given chemical element and the yield size. Bioaccumulation factors for heavy metals were calculated as a ratio of the content of a given chemical element to the doses introduced into the soil with the municipal sewage sludge compost and high-calcium brown coal ash ${ }^{22,23}$.

When evaluating the bioaccumulation factors of cadmium, copper, manganese, nickel, lead and zinc in the test plant, a four-point scale was adopted according to ${ }^{\mathbf{2 4}}$. The degree of accumulation was determined as: intense, average, poor and none, whereas the corresponding values of bioaccumulation factors are 1.0 to $10.0,0.1$ to $1.0,0.1$ to 0.01 and 0.001 to 0.01 , respectively.

\section{RESULTS AND DISCUSSION}

The biomass of Virginia fanpetals contained on average the most manganese $\left(24.7 \mathrm{mg} \cdot \mathrm{kg}^{-1} \mathrm{~d} . \mathrm{m}.\right)$, lead (2.50 mg $\cdot \mathrm{kg}^{-1}$ d.m.) and zinc (50.5 mg $\mathrm{kg}^{-1}$ d.m.) in 2008, while the most cadmium $\left(0.33 \mathrm{mg} \cdot \mathrm{kg}^{-1} \mathrm{~d} . \mathrm{m}.\right)$, copper (3.78 mg $\cdot \mathrm{kg}^{-1}$ d.m.) and nickel $\left(2.57 \mathrm{mg} \cdot \mathrm{kg}^{-1}\right.$ d.m.) in 2010 . Average copper, nickel and lead contents in test plant biomass slightly differed in particular study years and amounted to $2.78,2.54$ and $2.35 \mathrm{mg} \cdot \mathrm{kg}^{-1} \mathrm{~d} . \mathrm{m}$., respectively.

In the carried out experiment, average cadmium, copper, lead and nickel contents in Virginia fanpetals biomass were smaller and that of zinc was over three times larger than the findings ${ }^{\mathbf{2 0}}$. On the other hand, when comparing the obtained cadmium, lead and zinc contents in Virginia fanpetals biomass, they were higher in relation ${ }^{25}$. Average cadmium, copper, manganese, nickel, lead and zinc contents in test plant biomass were slightly higher, respectively by $14.3 \%, 10.0 \%, 7.3 \%$, $19.3 \%, 29.1 \%$ and $6.9 \%$, in the objects where municipal sewage sludge compost had been applied without and with addition of high-calcium brown coal ash (fertilisation objects III, IV and VI) when compared to those where only calcium carbonate or high-calcium brown coal ash had been introduced into soil (fertilisation objects I and II); see Tab. 1 and 2.

The biomass of Virginia fanpetals contained significantly more lead as affected by organic fertilisation without and with the addition of high-calcium brown coal ash when compared with the fertilisation objects where calcium carbonate or high-calcium brown coal ash had been introduced into the soil. The differences in the average content of other heavy metals in test plant biomass from the objects fertilised with municipal sewage sludge compost with and without the addition of high-calcium brown coal ash were not significant (Tab. 1 and 2).

The differences in cadmium, copper, manganese, nickel, lead and zinc contents in the test plant biomass between particular experimental objects were not significant.

The least average copper and zinc contents in Virginia fanpetals biomass were found in the object where highcalcium brown coal ash had been introduced into the soil at a dose corresponding to $1.5 \mathrm{Mg} \mathrm{CaO} \cdot \mathrm{ha}^{-1}$ in the first year of study and to $0.75 \mathrm{Mg} \mathrm{CaO} \cdot h a-1$ and annually (fertilisation object $\mathrm{V}$ ) when compared to those where calcium carbonate and high-calcium brown coal ash had been applied (fertilisation objects I and II), respectively by $12.6 \%$ and $11.7 \%$; see Tab. 1 and 2 . 
Table 1. The content of cadmium, copper and manganese in Virginia fanpetals biomass. The data are given in $\mathrm{mg} \cdot \mathrm{kg}^{-1} \mathrm{~d} . \mathrm{m}$.

\begin{tabular}{|c|c|c|c|c|}
\hline \multirow{3}{*}{ Fertilisation objects } & \multirow{3}{*}{ Study years } & \multicolumn{3}{|c|}{ Chemical element } \\
\hline & & $\mathrm{Cd}$ & $\mathrm{Cu}$ & $\mathrm{Mn}$ \\
\hline & & \multicolumn{3}{|c|}{ in $\mathrm{mg} \mathrm{kg}^{-1} \mathrm{~d} . \mathrm{m}$. } \\
\hline \multirow{3}{*}{ I. Carbonate lime $\left(\mathrm{CaCO}_{3}\right)$ at a dose corresponding to $1.5 \mathrm{Mg} \mathrm{CaO} \cdot \mathrm{ha}^{-1}$} & 2008 & 0.28 & 2.08 & 23.8 \\
\hline & 2009 & 0.25 & 2.02 & 17.6 \\
\hline & 2010 & 0.32 & 3.95 & 13.4 \\
\hline \multicolumn{2}{|l|}{ mean value } & 0.28 & 2.68 & 18.3 \\
\hline \multirow{3}{*}{ II. High-calcium brown coal ash at a dose corresponding to $1.5 \mathrm{Mg} \mathrm{CaO} \cdot \mathrm{ha}^{-1}$} & 2008 & 0.26 & 2.12 & 23.3 \\
\hline & 2009 & 0.22 & 1.96 & 18.1 \\
\hline & 2010 & 0.36 & 3.85 & 13.8 \\
\hline \multicolumn{2}{|l|}{ mean value } & 0.28 & 2.64 & 18.4 \\
\hline \multirow{3}{*}{ III. Municipal sewage sludge compost at a dose corresponding to $250 \mathrm{~kg} \mathrm{Neha}^{-1}$} & 2008 & 0.30 & 2.62 & 25.8 \\
\hline & 2009 & 0.30 & 2.54 & 18.8 \\
\hline & 2010 & 0.30 & 3.67 & 13.9 \\
\hline \multicolumn{2}{|l|}{ mean value } & 0.30 & 2.94 & 19.5 \\
\hline \multirow{3}{*}{$\begin{array}{l}\text { IV. Municipal sewage sludge compost at a dose corresponding to } 250 \mathrm{~kg} \mathrm{~N}^{-1} \mathrm{ha}^{-1} \\
\text { +high-calcium brown coal ash at a dose corresponding to } 1.5 \mathrm{Mg} \mathrm{CaO} \cdot \mathrm{ha}^{-1} \\
\text { (1st year of study) }\end{array}$} & 2008 & 0.30 & 2.68 & 25.9 \\
\hline & 2009 & 0.36 & 2.60 & 18.9 \\
\hline & 2010 & 0.39 & 3.84 & 14.3 \\
\hline \multicolumn{2}{|l|}{ mean value } & 0.35 & 3.04 & 19.7 \\
\hline \multirow{3}{*}{$\begin{array}{l}\text { V. High-calcium brown coal ash at a dose corresponding to } 1.5 \mathrm{Mg} \mathrm{CaO}^{-1} \mathrm{a}^{-1} \\
\text { (1st year of study) and to } 0.75 \mathrm{Mg} \mathrm{CaO}^{-1} \mathrm{a}^{-1} \text { in following study years }\end{array}$} & 2008 & 0.26 & 2.12 & 23.4 \\
\hline & 2009 & 0.25 & 2.02 & 18.0 \\
\hline & 2010 & 0.32 & 3.67 & 14.7 \\
\hline \multicolumn{2}{|l|}{ mean value } & 0.28 & 2.60 & 19.7 \\
\hline \multirow{3}{*}{$\begin{array}{l}\text { VI. Municipal sewage sludge compost at a dose corresponding to } 250 \mathrm{~kg} \mathrm{~N}^{-1} \mathrm{ha}^{-1} \\
\text { +high-calcium bron coal ash at a dose corresponding to } 1.5 \mathrm{Mg} \mathrm{CaO} \cdot \mathrm{ha}^{-1} \\
\text { (1st year of study) and to } 0.75 \mathrm{Mg} \mathrm{CaO} \cdot \mathrm{ha}^{-1} \text { in following study years }\end{array}$} & 2008 & 0.32 & 2.70 & 25.9 \\
\hline & 2009 & 0.32 & 1.98 & 18.8 \\
\hline & 2010 & 0.31 & 3.72 & 15.1 \\
\hline \multicolumn{2}{|l|}{ mean value } & 0.32 & 2.80 & 19.9 \\
\hline \multicolumn{2}{|l|}{ Mean value for fertilisation objects } & 0.30 & 2.78 & 19.2 \\
\hline \multicolumn{2}{|l|}{ LSD $_{0.05}$} & n.s. & n.s. & n.s. \\
\hline
\end{tabular}

The value of heavy metals uptake by Virginia fanpetals biomass depended on the yield size and the content of the chemical elements under discussion. The total uptake of heavy metals concerned is compared in Table 3.

The total uptake of heavy metals by Virginia fanpetals biomass from the objects fertilised with municipal sewage sludge compost with and without the addition of highcalcium brown coal ash being applied at the beginning of study and annually (fertilisation objects III, IV and VI) increased on average by $51.0 \%$ for lead, $33.2 \%$, for nickel, $32.2 \%$ for cadmium, $24.4 \%$ for manganese, $17.9 \%$ for copper and $17.4 \%$ for zinc when compared to that fertilised with calcium carbonate (fertilisation object I) (Tab. 3). The least zinc (1369 g.ha-1 d.m.) was absorbed by the test plant biomass in the object with high-calcium brown coal ash being applied in the first year of study and annually (fertilisation object V).

The uptake quantity was on average smaller by $17.2 \%$ when compared to fertilisation objects III, IV and VI. As a result of organic fertilisation with and without the addition of high-calcium brown coal ash being applied at the beginning of study and annually, the uptake of copper, manganese, nickel, lead and zinc by Virginia fanpetals biomass significantly increased when compared to fertilisation objects I and II. A significant increase in the uptake of manganese, nickel and lead by test plant biomass was found in the object fertilised with highcalcium brown coal ash when compared to that where carbonate lime had been introduced into the soil (Tab. 3). The effect of fertilisation with calcium carbonate, high- calcium brown coal ash and municipal sewage sludge compost on the total uptake of heavy metals by Virginia fanpetals biomass differed. The biomass of the test plant had absorbed significantly less heavy metals concerned from the objects fertilised with calcium carbonate or high-calcium brown coal ash when compared to those where organic fertilisation had been applied without and with addition of high-calcium brown coal ash.

The total uptake of cadmium, copper, manganese, nickel and lead by test plant biomass was the least in fertilisation objects I and II, while that of zinc in fertilisation object V (Tab. 3). When analysing the dynamics of heavy metals uptake, it was found to be decidedly smaller in the first year of study and ranged from $4.40 \%$ to $11.0 \%$. It increased in the second year of study, being within the limits of $29.9 \%$ to $47.9 \%$, while reached the largest value in the third year of study, oscillating between $39.7 \%$ and $65.7 \%$ (Fig. 1). It results from the carried out study ${ }^{20}$ that the total uptake of copper, manganese, nickel, lead and zinc by Virginia fanpetals biomass in this experiment was similar, whereas that of cadmium almost ten times smaller.

The uptake of heavy metals by Virginia fanpetals biomass, i.e. its mean value of three harvests during three years of its cultivation, can be arranged in the following descending order of values: $\mathrm{Zn}>\mathrm{Mn}>\mathrm{Cu}>\mathrm{Ni}>\mathrm{Pb}$ $>\mathrm{Cd}$. Different results were obtained ${ }^{26,27}$ which found that the quantity of heavy metals absorbed by plants could be presented as the following series: $\mathrm{Zn}>\mathrm{Cd}$ $>\mathrm{Ni}>\mathrm{Cu}>\mathrm{Pb}=\mathrm{Cr}$. The small uptake of copper 
Table 2. The content of nickel, lead and zinc in Virginia fanpetals biomass. The data are given in $\mathrm{mg} \cdot \mathrm{kg}^{-1} \mathrm{~d} . \mathrm{m}$.

\begin{tabular}{|c|c|c|c|c|}
\hline \multirow{3}{*}{ Fertilisation objects } & \multirow{3}{*}{ Study years } & \multicolumn{3}{|c|}{ Chemical element } \\
\hline & & $\mathrm{Ni}$ & $\mathrm{Pb}$ & $\mathrm{Zn}$ \\
\hline & & \multicolumn{3}{|c|}{ in $\mathrm{mg} \cdot \mathrm{kg}^{-1} \mathrm{~d} . \mathrm{m}$. } \\
\hline \multirow{3}{*}{ I. Carbonate lime $\left(\mathrm{CaCO}_{3}\right)$ at a dose corresponding to $1.5 \mathrm{Mg} \mathrm{CaO} \cdot \mathrm{ha}^{-1}$} & 2008 & 2.19 & 2.12 & 47.2 \\
\hline & 2009 & 1.94 & 1.95 & 47.1 \\
\hline & 2010 & 2.57 & 1.87 & 38.0 \\
\hline \multicolumn{2}{|l|}{ mean value } & 2.23 & 1.98 & 44.1 \\
\hline \multirow{3}{*}{ II. High-calcium brown coal ash at a dose corresponding to $1.5 \mathrm{Mg} \mathrm{CaO} \cdot \mathrm{ha}^{-1}$} & 2008 & 2.11 & 2.20 & 46.7 \\
\hline & 2009 & 2.04 & 2.16 & 46.3 \\
\hline & 2010 & 2.41 & 1.89 & 40.0 \\
\hline \multicolumn{2}{|l|}{ mean value } & 2.19 & 2.08 & 43.3 \\
\hline \multirow{3}{*}{ III. Municipal sewage sludge compost at a dose corresponding to $250 \mathrm{~kg} \mathrm{~N} \cdot \mathrm{ha}^{-1}$} & 2008 & 2.65 & 2.81 & 53.3 \\
\hline & 2009 & 2.55 & 2.80 & 51.6 \\
\hline & 2010 & 2.71 & 1.98 & 41.0 \\
\hline \multicolumn{2}{|l|}{ mean value } & 2.64 & 2.53 & 48.6 \\
\hline \multirow{3}{*}{$\begin{array}{l}\text { IV. Municipal sewage sludge compost at a dose corresponding to } 250 \mathrm{~kg} \mathrm{~N} \cdot \mathrm{ha}^{-1} \\
\text { +high-calcium brown coal ash at a dose corresponding to } 1.5 \mathrm{Mg} \mathrm{CaO} \cdot \mathrm{ha}^{-1} \\
\text { (1st year of study) }\end{array}$} & 2008 & 2.68 & 2.90 & 53.8 \\
\hline & 2009 & 2.58 & 2.88 & 52.5 \\
\hline & 2010 & 2.80 & 2.10 & 32.0 \\
\hline \multicolumn{2}{|l|}{ mean value } & 2.69 & 2.63 & 46.1 \\
\hline \multirow{3}{*}{$\begin{array}{l}\text { V. High-calcium brown coal ash at a dose corresponding to } 1.5 \mathrm{Mg} \mathrm{CaO} \cdot \mathrm{ha}^{-1} \text { (1st } \\
\text { year of study) and to } 0.75 \mathrm{Mg} \mathrm{CaO} \cdot \mathrm{ha}^{-1} \text { in following study years }\end{array}$} & 2008 & 2.16 & 2.20 & 47.0 \\
\hline & 2009 & 2.06 & 2.19 & 46.0 \\
\hline & 2010 & 2.43 & 2.23 & 32.5 \\
\hline \multicolumn{2}{|l|}{ mean value } & 2.22 & 2.21 & 41.8 \\
\hline \multirow{3}{*}{$\begin{array}{l}\text { VI. Municipal sewage sludge compost at a dose corresponding to } 250 \mathrm{~kg} \mathrm{~N} \cdot \mathrm{ha}^{-1} \\
\text { +high-calcium bron coal ash at a dose corresponding to } 1.5 \mathrm{Mg} \mathrm{CaO} \cdot \mathrm{ha}^{-1}(1 \mathrm{st} \\
\text { year of study) and to } 0.75 \mathrm{Mg} \mathrm{CaO} \cdot \mathrm{ha}^{-1} \text { in following study years }\end{array}$} & & 2.70 & & 55.0 \\
\hline & 2009 & 2.54 & 2.80 & 50.9 \\
\hline & 2010 & 2.51 & 2.48 & 30.5 \\
\hline \multicolumn{2}{|l|}{ mean value } & 2.58 & 2.70 & 45.5 \\
\hline \multicolumn{2}{|l|}{ Mean value for fertilisation objects } & 2.54 & 2.35 & 44.9 \\
\hline \multicolumn{2}{|l|}{$\mathbf{N I R}_{0,05}$} & n.s. & 0.572 & n.s. \\
\hline
\end{tabular}

Table 3. Total cadmium, copper, manganese, nickel, lead and zinc uptake by Virginia fanpetals biomass in 2008-2010. The data are given in $\mathrm{g} \cdot \mathrm{ha}^{-1} \mathrm{~d} . \mathrm{m}$.

\begin{tabular}{|c|c|c|c|c|c|c|}
\hline \multirow{3}{*}{ Fertilisation objects } & \multicolumn{6}{|c|}{ Chemical element } \\
\hline & $\mathrm{Cd}$ & $\mathrm{Cu}$ & $\mathrm{Mn}$ & $\mathrm{Ni}$ & $\mathrm{Pb}$ & $\mathrm{Zn}$ \\
\hline & \multicolumn{6}{|c|}{ in $\mathrm{g}^{\cdot} \mathrm{kg}^{-1}$ d.m. } \\
\hline I & 9.48 & 98.6 & 526.2 & 75.0 & 63.6 & 1409 \\
\hline II & 9.59 & 95.5 & 539.3 & 73.4 & 67.0 & 1427 \\
\hline III & 11.2 & 115.1 & 630.1 & 98.1 & 89.4 & 1733 \\
\hline IV & 14.1 & 122.6 & 654.0 & 102.8 & 95.5 & 1624 \\
\hline $\mathrm{V}$ & 9.89 & 98,4 & 580.1 & 77.9 & 76.7 & 1369 \\
\hline $\mathrm{VI}$ & 12.3 & 112.2 & 680.2 & 98.8 & 103.1 & 1606 \\
\hline Mean & 11.1 & 107.1 & 601.6 & 87.7 & 82.5 & 1528 \\
\hline $\mathrm{NIR}_{0,05}$ & n.s. & 0.10 & 0.09 & 0.87 & 3.13 & 0.305 \\
\hline
\end{tabular}

${ }^{*}$ Description of fertilisation objects is given in Table 1.

(107.1 g.ha ${ }^{-1}$ d.m.), nickel (87.7 g.ha ${ }^{-1}$ d.m.) and lead $\left(82,5 \mathrm{~g} \cdot \mathrm{ha}^{-1}\right.$ d.m.) by Virginia fanpetals biomass during the three study years should be explained by the bonding of chemical elements under discussion by organic matter and the formation of chelate bonds in the soil ${ }^{28,29}$. The limited uptake of nickel by plants from the soil fertilised with sewage sludge or sewage sludge compost may also result from the selectivity of this process. Antonkiewicz and Jasiewicz ${ }^{30}$ tested several species of energy crops and found that Virginia fanpetals biomass accumulates large quantities of metals and is resistant to their high concentrations in the tissues of overground parts, and therefore it is possible to use this plant for land reclamation purposes.
The biomass of the test plant did not absorb large quantities of heavy metals since they had not been brought into the soil with municipal sewage sludge and high-calcium brown coal ash in considerable amounts, whereas the soil itself did not contain their excessive amounts.

When evaluating the usefulness of Virginia fanpetals biomass for the use of heavy metals from the compost produced with municipal sewage sludge and high-calcium brown coal ash, cadmium, copper, manganese, nickel, lead and zinc, bioaccumulation factors were calculated (Tab. 4). When calculating the degree of bioaccumulation, fertilisation object I, where municipal sewage sludge 
Table 4. Bioaccumulation factors for heavy metals in Virginia fanpetals biomass in 2008-2010 as affected by municipal sewage sludge compost and high-calcium brown coal ash

\begin{tabular}{|c|c|c|c|c|c|c|}
\hline \multirow{2}{*}{ Fertilisation objetcs } & \multicolumn{6}{|c|}{ Chemical element } \\
\hline & $\mathrm{Cd}$ & $\mathrm{Cu}$ & $\mathrm{Mn}$ & $\mathrm{Ni}$ & $\mathrm{Pb}$ & $\mathrm{Zn}$ \\
\hline II & $\frac{1.314}{\text { intense }}$ & $\frac{1.211}{\text { intense }}$ & $\underline{0.880}$ & $\frac{2.201}{\text { intense }}$ & $\frac{1.625}{\text { intense }}$ & $\frac{2.372}{\text { intense }}$ \\
\hline III & $\underline{0.700}$ & $\underline{0.153}$ & $\underline{0.184}$ & $\underline{0.754}$ & $\frac{1.150}{\text { intense }}$ & $\underline{\underline{0.850}}$ \\
\hline IV & $\underline{0.546}$ & $\underline{0.142}$ & $\underline{0.155}$ & $\underline{0.598}$ & $\underline{0.755}$ & $\underline{0.611}$ \\
\hline V & $\underline{0.886}$ & $\underline{0.802}$ & $\underline{0.632}$ & $\frac{1.500}{\text { intense }}$ & $\frac{1.163}{\text { intense }}$ & $\frac{1.540}{\text { intense }}$ \\
\hline $\mathrm{VI}$ & $\underline{0.567}$ & $\underline{0.124}$ & $\underline{0.145}$ & $\underline{0.518}$ & $\underline{\underline{0.658}}$ average & $\underline{0.539}$ \\
\hline Mean value & $\begin{array}{c}\underline{0.802} \\
\text { average }\end{array}$ & $\underline{\underline{0.486}}$ average & $\begin{array}{c}\underline{0.399} \\
\text { average }\end{array}$ & $\frac{1.114}{\text { intense }}$ & $\frac{1.070}{\text { intense }}$ & $\frac{1.182}{\text { intense }}$ \\
\hline
\end{tabular}

* Description of fertilisation objects is given in Table 1.

compost nor high-calcium brown coal ash had not been applied, was omitted.

The bioaccumulation factor for heavy metals in Virginia fanpetals biomass differed, depending on the fertilisation applied. The degree of cadmium, copper, nickel, lead and zinc accumulation was intense after three study years in the object where high-calcium brown coal ash had been applied at a dose corresponding to $1.5 \mathrm{Mg}$ $\mathrm{CaO} \cdot \mathrm{ha}^{-1}$, while that for manganese was average $(0.880)$. In the objects with high-calcium brown coal ash being introduced into the soil at a dose corresponding to 1.5 $\mathrm{Mg} \mathrm{CaO} \cdot \mathrm{ha}^{-1}$ in the first year of study and to $0.75 \mathrm{Mg}$ $\mathrm{CaO} \cdot \mathrm{ha}^{-1}$ in the following study years and with municipal sewage sludge compost and an annual application of highcalcium brown coal ash (fertilisation objects V and VI), an intense degree of accumulation in Virginia fanpetals biomass was found in the case of nickel, lead and zinc, whereas an average one for other heavy metals (Tab. 4). Municipal sewage sludge compost being introduced into soil at a dose corresponding to $250 \mathrm{~kg} \mathrm{~N} \cdot \mathrm{ha}^{-1}$ and with high-calcium brown coal ash at a dose corresponding to $1.5 \mathrm{Mg} \mathrm{CaO} \cdot \mathrm{ha}^{-1}$ in the first year of study induced an average degree of accumulation of all chemical elements under discussion in test plant biomass. An intense degree of accumulation in test plant biomass was characteristic of lead (1.150) in the object where organic fertilisation had been only applied (fertilisation object III), whereas other heavy metals showed an average accumulation. It was also found that the higher the content of a given heavy metal being brought into soil with municipal sewage sludge compost with and without the addition of highcalcium brown coal ash, the smaller bioaccumulation factor in Virginia fanpetals biomass.

The reason of average heavy metals bioaccumulation in Virginia fanpetals biomass was alkaline reaction of municipal sewage sludge compost (8.50) and high-calcium brown coal ash $\left(\mathrm{pH}_{\mathrm{KCL}} 11.0\right)$. This induced a weak mobility of these chemical elements and their small sorption. It results from the studies carried ${ }^{31,32}$ that some heavy metals form chelate complexes with organic matter in the soil, the bond strength which increases together with an increase in the soil $\mathrm{pH}$.

The average bioaccumulation of heavy metals may be the result of organic matter introduction with compost and increased soil sorption capacity ${ }^{33,34}$. It results from the studies carried ${ }^{35-37}$ that the complexing properties increase in the soil being fertilised with composts, as a result of which stable metal-organic associations that limit the availability of heavy metals for plants are formed. On the other hand, high-calcium brown coal ashes do not have a negative effect on the chemical and biological processes taking place in the soil ${ }^{38}$.

\section{CONCLUSIONS}

1. Virginia fanpetals biomass contained on average the most manganese, lead and zinc in 2008, while the most cadmium, copper and nickel in 2010.

2. Average cadmium, copper, manganese, nickel, lead and zinc contents in the test plant biomass were higher, respectively by $14.3 \%, 10.0 \%, 7.3 \%, 19.3 \%, 29.1 \%$ and $6.9 \%$, in the objects where municipal sewage sludge compost had been applied with and without the addition of high-calcium brown coal ash when compared to those where calcium carbonate or high-calcium brown coal ash had been introduced into the soil at a dose corresponding to $1.5 \mathrm{Mg} \mathrm{CaO} \cdot \mathrm{ha}^{-1}$.

3. Differences in cadmium, copper, manganese, nickel, lead and zinc contents in Virginia fanpetals biomass between particular experimental objects were not significant.

4. The total uptake of heavy metals by Virginia fanpetals biomass from the objects fertilised with municipal sewage sludge with and without the addition of highcalcium brown coal ash being applied at the beginning of the study and annually increased when compared to that fertilised with calcium carbonate.

5. The least zinc was absorbed by the test plant biomass in the object with high-calcium brown coal ash being applied in the first year of the study and annually.

6. The bioaccumulation factor for heavy metals in Virginia fanpetals biomass differed, depending on the fertilisation applied. The degree of heavy metals accumulation in Virginia fanpetals biomass oscillated between intense and average.

\section{LITERATURE CITED}

1. Antonkiewicz, J. (2007). Effect of ash-sludge mixtures and peat ash on the yield of grass mixtures Birdsfoot trefoil and the contents of selected elements in the mix. Acta Sci. Pol. Formatio Circumiectus 6 (3), 61-72 [in Polish].

2. Kalembasa, S., Godlewska, A. \& Wysokiński, A. (2008). The chemical composition of ashes from brown coal and coal in terms of agricultural development. Rocz. Glebozn. LIX (2), 93-97 [in Polish]. 


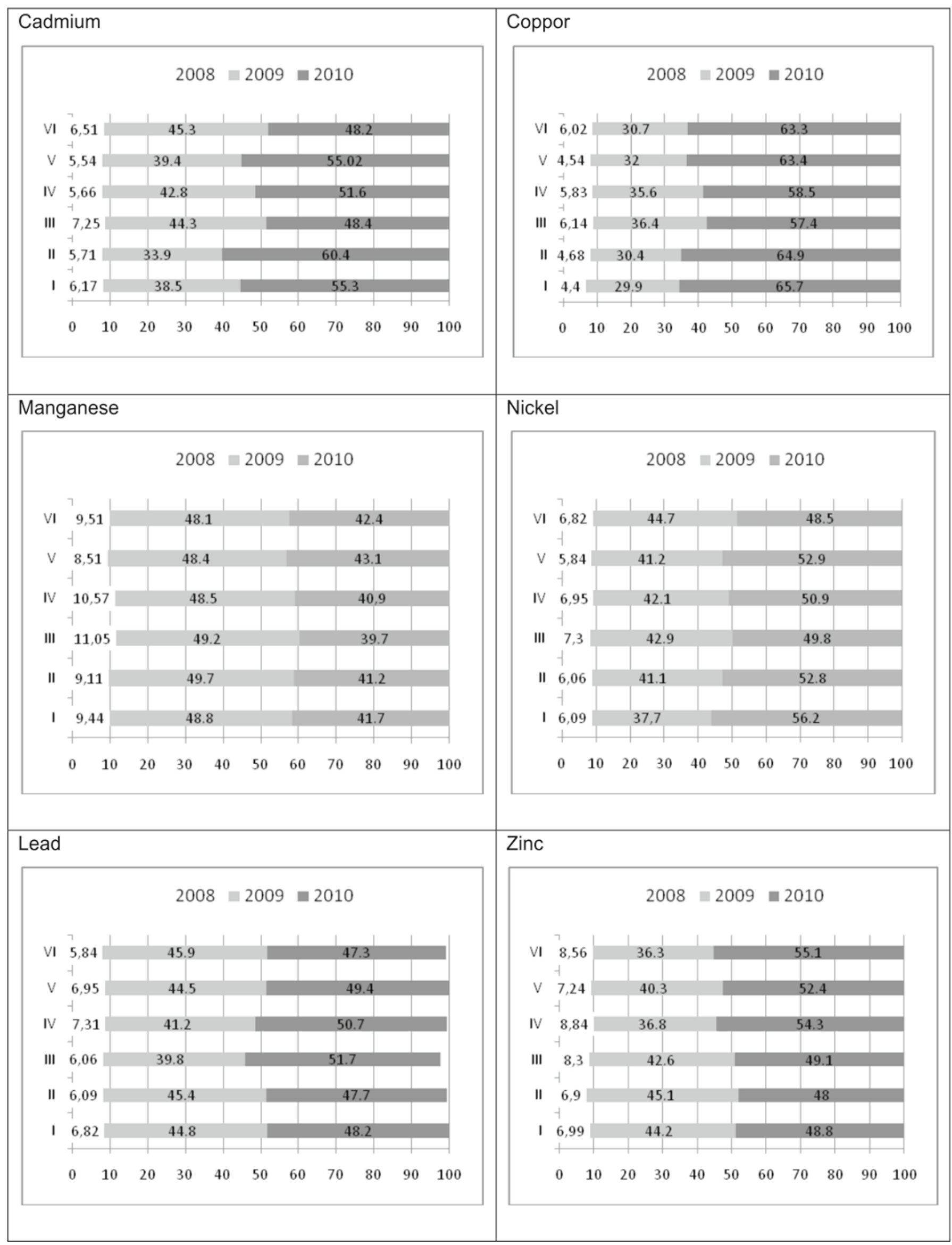

Figure 1. Dynamics of heavy metals uptake by Virginia fanpetals biomass in successive years of cultivation in relative values (total uptake $=100 \%$ ). The description of fertilisation objects (I to VI) is given in Table 1

3. Kovàcik, P., Macàk, M., Ducsay, L., Halcćinovà, M. \& Janćich, M. (2011). Efect of ash-fly ash mixture application on soil fertility. J. Elem. 16(2):215-225. DOI: 10.5601/jelem.2011.16.2.05.

4. Cai, Q.Y., Mo, C.H., Wu, Q.T., Zeng, Q.Y.\& Katsoyian- nis, A. (2007) Contentration andspeciation of heavy metals in six different sewage sludge-composts. $J$ Hazard Mat. 147: 1063-1072. DOI. 10.1016/j.jhazmet.2007.01.142.

5. Strzyszcz, Z. \& Bzowski, Z. (1993). The content of chromium and nickel in coals of stone, and the size of the depo- 
sition of these metals in the Southeast part of the province of Katowice..[W:] Chrom, nikiel i glin w środowisku - problemy ekologiczne i metodyczne. Zesz. Nauk. Komit. „Człowiek i Środowisko". PAN, 5, 93-98 [in Polish].

6. Kwiatkowska, B., Cierpiszewski, R. \& Domka, F. (2006). The impact of acid precipitation on the texture of fly ash and bioavailable metals. Ekol. Tech., 14,2, 53-58 [in Polish].

7. Czekała, J. (2002). Value and performance of sewage sludge fertilizer. Folia Univ. Agric. Stetin. Ser. Agriculturae 211,(84), 75-80 [in Polish].

8. Czekała, J. (2008). Chemical properties of compost produced from municipal sewage sludge and various bio-waste. Journal of Research and Applications in Agricultural Engineering. Vol. 53, (3), 35-41[in Polish].

9. Gambuś, F. (1999). The chemical composition and fertilizer value of sewage sludge from sewage treatment selected region of krakowskiego. [w: Przyrodnicze użytkowanie osadów ściekowych]. Materiały III Konferencji Naukowo-Technicznej. Świnoujście 9-11 czerwca. Ekoinżynieria, Lublin, 60-77 [in Polish].

10. Krzywy, E., Wołoszyk, C. \& Iżewska, A. (2000). The value of municipal sewage sludge fertilizer. Wyd. PTIE, Oddziat Szczeciński, 5-58 [in Polish].

11. Krzywy-Gawrońska, E. (2009). Investigations of the effect of compost from municipal sewage sludge and the active substance PRP Sol on soil fertility and productivity. Wyd. ZUT w Szczecinie, 96 [in Polish].

12. Bose, S., Jain, A., Rai, V. \& Ramanathan, A.L. (2008). Chemical fractionation and translocation of heavy metals in Canna indica L.grown on industrial soil. J. Hazard. Mater., 160, 187-193. DOI: 10.1016/j.jhazmat.2008.02.119.

13. Torri, S.I.\& Lavado, R. (2008). Zinc distribution in soils amended with different kinds of sewage sludge. J. Environ. Manage. 88 (4), 1571-1579. DOI: 10.1016/j.jenvman. 2007.07.026.

14. Haroun, M., Idris, A. \& Omar, S. R. S. (2007). A study of heavy metals and their fate in the composting of tannery sludge. Waste Management 27 (11), 1541-1550. DOI:10.1016/j. wasman.2006.09.006

15. Bernacka, E. \& Pawłowska, L. (2000). Potentially toxic substances in the sediments, municipal wastewater treatment plant. Monografia. IOŚ. Warszawa [in Polish].

16. Harrison, E.Z., Oakes, S.R., Hysell M. \& Hay A. (2006). Organic chemical in sewage sludges. Sci. Total Envirion. 367, 481-487. DOI: 10.1016/j.scitotenv.2006.04.002.

17. Bień, J.B. (2007). Sewage sludge. Theory and practice. Wyd. Politech. Częstoch., Częstochowa, 289 [in Polish].

18. Jackowska, I. \& Olesiejuk A. (2004). Evaluation of the usefulness of sewage sludge treatment plant in Lubartów for agricultural use. Annales. UNCS LIX (2), 1001-1006 [in Polish].

19. Regulation of the Minister of Environment on municipal sewage sludge. Official Journal of Laws No. 137, item 924 of 2010 [in Polish].

20. Borkowska, H. \& Styk, B. (2006). Ślazowiec Pennsylvanian. Cultivation and use. Wyd. AR Lublin, 68 [in Polish].

21. Krzywy-Gawrońska, E. (2011). The effect of industrial wastes and municipal sewage sludge compost on the quality of virginia fanpetals (SIDA HERMAPHRODITA RUSBY) biomass. Part 1. Macroelements content and their upatke dynamics. Praca oddana do recenzji 13/1/2012.

22. Siuta, J. (1988). Natural management of sewage sludge. Wyd. PWN Warszawa, 172. [in Polish].

23. Kabata-Pendias, A., \& Pendias, H. (2000). Trace Elements in Soils and Plants. (3 rd ed.) CRC press:413.

24. Michałowski, M., \& Gołaś, J. (2001). Contents of selected heavy metals in the organs of willow as an indicator to use it in the disposal of sewage sludge. Zesz. Probl. Post. Nauk Rol. 477, 411-419 [in Polish].

25. Łabętowicz, J., \& Stępień, W. (2010). Fertilization of energy crops (willow, miscanthus, ślazowiec). Modern tech- nology acquisition and utilization of biomass energy. Instytut Energetyki, 89-100 [in Polish].

26. Moreno, J.L., Garcia, C., Hernandez, T., \& Pascual, J.A. (1997). Transference of heavy metals from a calcarceous soil amended with sewage sludge compost to barley plants. Bioresourtechnol. 3, 251-258.

27. Piotrowski, J. \& Jackowska, I. (1996). Heavy metals from the environments to ecosystems. Zesz. Probl. Post. Nauk Rol. 434, 931-935 [in Polish].

28. Mangel, K. \& Kirkby, E.A. (1983). Basics of plant nutrition. PWRiL, Warszawa ss:526 [in Polish].

29. Roszyk, E., Roszyk, S. \& Spiak, Z. (1987). Fertilizer value of sewage sludge from treatment of some south-western Polski. Rocz. Gleboz. 38 (3), 93-102 [in Polish].

30. Antonkiewicz, J. \& Jasiewicz, Cz. (2000). Extraction of heavy metals by plants from soils contaminated with heavy metals. Zesz. Probl. Post. Nauk Rol. 472 [in Polish].

31. Gorlach, E., Gambuś, F. \& Michniak, A. (1990). The efekt of $\mathrm{pH}$ on the uptake of heavy metals by litalian Ryegrass (Lolium multiflorum) in the conditions of their differentiated contents in soil. Pol. J. Soil Sci. 23 (1):17-23 [in Polish].

32. Randal, S.S. \& Bruce, R.J. (1991). Zinc sorption by B Horizon soil as a function of pH. Soil. Sci. Soc. Am. J., 55, 159-597.

33. Wiater J. \& Dębicki, R. (1994). Subsequent interaction of various organic materials to soil and plant. Cz. I. Selected elements of soil fertility. Zesz. Probl. Post. Nauk Rol. 407, 54-64 [in Polish].

34. Baran, S., Bielińska, J. \& Wiśniewski, J. (1998). The effect of non-conventional compound fertilizers on selected soil properties of light. Folia Univ. Agric. Stetin., Ser. Agriculturae 190 (72), 11-20 [in Polish].

35. Mazur, T. (1995). Agricultural and ecological importance of soil organic matter. Zesz. Probl. Post. Nauk Rol. 422, 9-17 [in Polish].

36. Baran, S., Flis-Bujak, M., Turski, R. \& Żukowska, G. (1996). Changes in physico-chemical properties of sandy soil fertilized with sewage sludge. Rocz. Glebozn. 47 (3/4), 123-130 [in Polish].

37. Flis-Bujak, M., Baran S. \& Żukowska, G. (1996). Properties of organic matter of selected waste of a fertilizer. Zesz. Probl. Post. Nauk Rol. 437, 147-153 [in Polish].

38. Gilewska, M. (2006). Processing and utilization of high-calcium cinders. Quality parameters of coal carbon and cinders produced during combustion in power plant. Materiaty Międzynarodowego Seminarium Naukowo-Technicznego. Wyd. Ekotech Betchatów, 285-293 [in Polish]. 